\title{
БІЛІНГВАЯЬНЕ НАВЧАННЯ МАЙБУТНІХ УЧИТЕЛІВ ПРИРОДНИЧИХ НАУК ЯК ВИМОГА СЬОГОДЕННЯ
}

У статті актуалізується проблема впровадження елементів білінгвального навчання у професійну підготовку майбутніх учителів природничої освітньої галузі. Встановлено, що в Украйні є значний історичний досвід запровадження білінгвальної освіти в закладах загальної середньої освіти. Виявлено, що існують проблеми підготовки майбутніх учителів, які могли б забезпечити вивчення природничих предметів школярами на двох мовах.

Висвітлено контент вибіркової навчальної дисципліни «Підготовка вчителів природничх наук в університетах США», вивчення якої здійснюеться англійською мовою, що є одним із засобів забезпечення «паритетної моделі» білінгвальної освіти майбутніх учителів природничої галузі, та «моделі, щзо витісняє». Вивчення цієё навчальної дисциипліни передбачає двоєдину мету - формування у студентів системи знань про концепціюо підготовки вчителів природничого профілю в США (структуру, особливості змісту, форм й методів навчання вчителів природничих наук в умовах неперервної педагогічної освіти) та адаптацію циих знань до освітнього процесу в Україні; формування навичок міжкультурної взаємодії. Специцікою євикладання англійською мовою, залежно від рівня сформованості іншомовної компетентності студентів.

Встановлено, що ефективною при вивченні навчальної дисципліни є методика навчання iз використанням різної дози допомоги (за Ю. Бабанським) при виконанні пізнавальних завдань. Ї̈ використання дозволяе забезпечити кожному студентові оптимальні умови для максимального задоволення його пізнавальних потреб, формування комунікативних умінь. Вона передбачає поступовий перехід від колективних форм роботи до частково самостійних і повністю самостійних, виконання завдань, складність яких поступово зростає.

Ключові слова: білінгвальна освіта, майбутні вчителі, вибіркова навчальна дисиципліна, контент, доза допомоги.

Постановка проблеми. Інформаційна єдність сучасного світу спонукає до проведення нової іншомовної політики в Україні, перегляду цілей навчання іноземної мови у закладах вищої освіти на немовних факультетах і запровадження нового змісту навчання, а також розробки сучасних технологій, які сприяли бдосягненню поставлених цілей. Результатом такого нововведення має стати формування фахівця, здатного здійснювати міжкультурне професійне спілкування, а також самовдосконалення та самоосвіту. Це сприяло виникненню у світовій освітній практиці такого явища, як білінгвальна освіта, яка передбачае залучення до світової культури за допомогою рідної та іноземної мов, коли іноземна мова діє як засіб пізнання світу, здобуття спеціальних знань, оволодіння культурним, історичним та суспільним досвідом різних країн і народів.

В Україні розвиток білінгвальної освіти, який зумовлений сучасною загальною тенденцією до інтеграції у європейський простір, прагненням до діалогу культур і міжкультурної комунікації, має певні історичні корені. Так, у 60-х - 70-х роках XX ст. у загальноосвітніх середніх школах із погдибленим вивченням іноземної мови активно

*(C) Олендр T. М.

*C) Степанюк А. B.

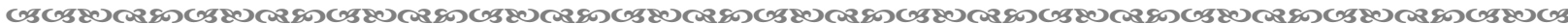


впроваджувались технології білінгвального навчання. 3 власного досвіду авторам відомо, що в той час, приміром, в ЗСШ № 3 м. Тернополя в основній школі вивчались такі предмети іноземною мовою (англійською): «Географія» (6 кл); «Англійська мова». У старшій школі до навчального предмета «Англійська мова» додавались «Англійська література», «Американська література», «Технічний переклад», «Військово-морські сили США». Практикувались по вівторках політінформації англійською мовою. Причому їх проводили для всіх учнів старших класів. Щотижня проводився день ангдійської мови, коди трансляція всіх передач через шкільний радіовузол здійснювалась іноземною мовою. Цей досвід активно використовують у наш час. Але, як і тоді, так і в теперішніх умовах існуе проблема підготовки вчителів, які б мали, приміром, природничу освіту i могли навчати школярів англійською мовою. Все це актуалізуе проблему впровадження білінгвального навчання у професійну підготовку майбутніх учителів природничих наук.

Аналіз досліджень. Стан та перспективи підготовки майбутніх учителів природничої освітньої галузі були предметом нашого дослідження [12]. Щодо білінгвальної освіти, то проведений аналіз літературних джерел засвідчив, що теоретичні основи білінгвізму в Україні знайшли відображення у працях таких науковців, як Т. Боднарчук [1; 9], О. Горошкіна [2] Н. Микитенко [5], С. Цюра [9] С. Ситняківська [7; 8], М. Хливнюк [7], А. Ширин [10] та інших. Їх дослідженнями встановлено, що білінгвальна освіта (bilingual education) - освіта, у процесі якої використовуються дві мови - рідна (перша) та друга (іноземна). Форми використання двох мов, а також види дидактичних матеріалів та їхня мова не регламентується, але їхній рівень має відповідати середній мовній компетенції референтної групи. У нашій публікації [6] частково висвітлено проблему впровадження елементів білінгвальної освіти в професійну підготовку майбутніх учителів природничих наук. Перевага такої освіти - крок у напрямку до мультикультурної освіти. Недоліки пов' язані 3 недосконалістю системи підготовки білінгвальних педагогів та відсутністю відповідних навчальних посібників. Встановлено, що білінгвальне навчання - це різноманіття моделей та програм, об'єднаних єдиним принципом: як засіб навчання вживаються дві мови [6]. Відомі такі моделі білінгвальної освіти: дублююча чи супроводжуюча; аддитивна (доповнююча); паритетна; модель, що витісняе. Проте сьогодні усі вони потребують подальшого дослідження.

Метою статті є висвітлення контенту вибіркової навчальної дисципліни «Підготовка вчителів природничих наук в університетах США», вивчення якої відбувається ангдійською мовою, як одним із засобів забезпечення моделі, що витісняе, та паритетної моделі білінгвальної освіти майбутніх учителів природничої освітньої галузі.

Викдад основного матеріалу. При розробці проблеми впровадження елементів білінгвальної освіти у професійну підготовку майбутніх учителів природничих наук ми виходили із припущення, що таке навчання більш ефективне, ніж класичне. Воно сприяе розвитку у здобувачів освіти загальних компетентностей, які у майбутньому дадуть можливість конкурувати не лише на українському, а й на світовому ринку праці. При цьому враховувалась аксіома, що вирішення проблеми постійного вдосконалення професійної підготовки майбутніх учителів у вищих педагогічних навчадьних закдадах буде ефективним, якщо вона відбуватиметься не тільки з урахуванням кращих зразків української педагогічної освіти, а й із запровадженням позитивного досвіду професійної підготовки вчителів за кордоном, зокрема в США. Саме у цій країні полікультурна освіта має статус державної політики, закріплений на законодавчому рівні (Billingual Education Act - Акт про білінгвальну освіту), встановлено спеціальну одиницю вимірювання ступеня старіння компетентності - «період напіврозпаду знань» (half-life of knowledge), що актуалізуе необхідність трактування освіти як неперервного процесу 
навчання. Крім того, США демонструють високий рівень розвитку природничої освіти, а отже і професійної компетентності педагогічних працівників [10].

3 метою запровадження білінгвальної освіти в професійну підготовку вчителя ми розробили програму навчальної дисципліни «Підготовка вчителів природничих наук в університетах США», яка $є$ результатом наукових розвідок Т. Олендр, А. Степанюк та Н. Щур [11]. Цей курс належить до блоку вибіркових дисциплін методичного спрямування. Його вкдючено до навчадьного плану підготовки здобувачів другого (магістерського) рівня вищої освіти спеціальності 014.15 Середня освіта (Природничі науки) та 014.05 Середня освіта (Біологія та здоров'я людини) хімікобіологічного факультету Тернопільського національного педагогічного університету імені Володимира Гнатюка і запроваджено курс. Вивчення навчальної дисципліни передбачає двоєдину мету - формування у студентів системи знань про концепцію підготовки вчителів природничого профілю в США (структуру, особливості змісту, форм і методів навчання вчителів природничих наук в умовах неперервної педагогічної освіти); формування навичок міжкультурної взаємодії. Специфікою є викладання ангдійською мовою, залежно від рівня сформованості іншомовної компетентності студентів.

Оскільки на другий (магістерський) рівень вищої освіти зараховують студентів із різною базою знань та навичок з іноземної мови, то для формування іншомовної компетенції у здобувачів викдадачеві доводиться використовувати різні методики та підходи у процесі навчання іноземної мови. Досвід проведення навчальних занять дозволяє констатувати, що ефективною є методика навчання із використанням різної дози допомоги (за Ю. Бабанським) при виконанні пізнавадьних завдань. Її використання дозволяє забезпечити кожному студентові умови для максимального задоволення його пізнавальних потреб і інтересів у процесі засвоєння навчального матеріалу, формуванні комунікативних умінь. Плануючи завдання, викладач враховує рівень володіння студентом іноземною мовою, а це дає мождивість створювати завдання різного рівня скдадності й, відповідно, групи для обговорення тем. При дозуванні викдадачем допомоги студентам він сам пропонуе завдання, але об'єм дозування допомоги залежить від студента. У процесі такого навчання здійснюється поступовий перехід від колективних форм роботи до частково самостійних і повністю самостійних. Такий підхід передбачає виконанні завдань, складність яких зростає.

Отже, у процесі викладання курсу відбувається певне узагальнення всіх знань і умінь, що їх отримав студент у межах навчання на природничих спеціальностях в університеті (зокрема, під час проходження педагогічної та науково-педагогічної практик) i, на основі отриманих знань, порівняння процесу формування професійнометодичної компетентності майбутнього вчителя природничих наук в Україні та США. Викладання курсу англійською мовою забезпечуе значне покращення іншомовної компетентності. Обсяг дисципліни становить 3 кредити ЕСТS, загальна кількість годин 90. На лекції відводиться 10 год., на практичні заняття - 20 год., а решта 60 год., на самостійну та індивідуальну роботу магістрантів [5].

Декційна частина курсу охоплюе вивчення загальних питань, що стосуються особливостей організації та змісту професійної підготовки майбутніх учителів природничих наук у США, форм та методів професійної підготовки та моніторингу якості природничої освіти в університетах США. Так, студентам пропонуються дия вивчення такі теми: «Становлення професіоналізму майбутнього вчителя природничих наук та його професійно-методична компетентність», «Нормативні джерела конструювання змісту підготовки вчителя природничих наук США», «Зміст, форми та методи професійної підготовки вчителів природничих наук до початку педагогічної діяльності», «Організація професійного навчання вчителів природничих наук упродовж педагогічної діяльності», «Методи професійного навчання вчителів у США», «Особливості організації професійної підготовки майбутніх учителів

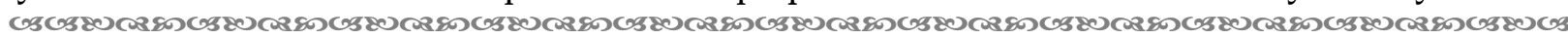


природничих наук у США та Україні», «Поняття моніторингу. Сутність і критерії моніторингу освіти в університетах США», «Структура й стандарти природничої освіти в університетах США», «Моніторингові дослідження якості навчальних досягнень студентів в університетах США», «Процес і результат як складові моніторингу якості природничої освіти» та ін.).

Практичні заняття спрямовані на поглиблення змісту головних тем лекційної частини курсу через вивчення компонентів, які забезпечують високий професіоналізм вчителя природничих наук у США; основних нормативних джерел, які визначають сутність професійної підготовки та педагогічної діяльності вчителів природничих наук уСША; особливостей навчальних програм підготовки вчителів природничих наук у США; методів професійного навчання вчителів природничих наук у США тощо.

Зміст дисципліни розділено на два тематичних модуді: «Підготовка вчителя природничих наук у США» та «Моніторинг якості природничої освіти в США». 3 огляду на те, що зміст курсу чітко структурований, його обсяг можна легко розширювати, а також теми можна варіювати. Самостійна робота студентів передбачає опрацювання літературних наукових джерел із проблем, які частково розкривають у процесі читання лекцій або обговорюють на практичних заняттях.

На самостійне опрацювання здобувачів вищої освіти виносяться навчальні матеріали, які за рівнем складності доступні для самостійного вивчення; розширюють, доповнюють, детадізують знання основ, викладених у базовому курсі; матеріади практичного спрямування, тобто такі, які ілюструють застосування загальних принципів, а саме: компоненти професійного навчання вчителів природничих наук уСША; основні етапи проходження педагогічної практики у школі; види методів професійного навчання, які реалізуються у процесі вивчення природничих наук та їх характеристика; основні відмінності між українською та американською системами педагогічної освіти; порівняльний аналіз змістового наповнення американських та українських програм підготовки майбутніх учителів природничих наук; характеристика вимог до професій галузі знань «Природничі науки» тощо. Кількість годин, відведених на самостійну роботу здобувачів, становить 52 год.

Метою самостійної роботи здобувача $є$ формування самостійності у здобутті та поглибленні знань, що сприятиме підвищенню конкурентоспроможності майбутніх фахівців на ринку праці. Практичний досвід i спостереження засвідчують, що самостійна робота стає ефективною при навчанні англійської мови за професійним спрямуванням на старших курсах, оскільки вона дає можливість оптимізувати навчальний процес в умовах зайнятості магістрів проєктами, дисциплінами за фахом, підготовкою кваліфікаційної магістерської роботи. 3 метою вдосконалення організації самостійної роботи здобувачів вищої освіти успішно застосовуються інформаційні технології та електронне навчальне середовище. Необхідно відзначити, що за таких умов покращуються результати навчання, магістранти одержують додаткові навички роботи 3 інформацією, які також підвищують мотивацію. Дуже важливим результатом такого навчання є формування умінь планувати й організовувати свою навчальну стратегію, розвиток навичок автономного навчання. При цьому змінюеться роль викладача, який із традиційного наставника перетворюється на організатора й модератора навчального процесу. Викладач виконує роль партнера й помічника, підтримуючи, направляючи і контролюючи пізнавальну діяльність майбутніх фахівців. Одним із головних завдань для викладача стає правильна організація навчального процесу.

Дослідницька робота студентів спрямована на овододіння навиками самостійного опрацювання інформації (передусім - інформації з електронних джерел). Зокрема, студенти самостійно здійснюють аналіз і порівняння елементів українського, американського й європейського досвіду 3 підготовки вчителів природничих наук, а також укладають словник до тем і перекладають реферовані тексти. Окрім цього, здобувачі досліджують процес сертифікації вчителів природничих наук. Цікавим

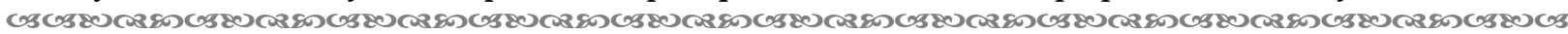
176 
прикладом дослідницької роботи є розвідки, пов'язані з прикладами розроблення плану уроку та підготовкою до його проведення. Для забезпечення інтеграції навчальної та науково-дослідницької діяльності здобувачів освіти на офіційному веб-сайті ТНПУ створено веб-сторінку «Науковий поступ», на якій розміщено збірник наукових праць «Наукові записки Тернопільського національного педагогічного університету ім. В. Гнатюка. Серія «Біологія» та матеріали щорічних міжнародних науковопрактичних конференцій «Підготовка вчителів фізики, хімії, біології та природничих наук у контексті вимог Нової української школи» $\mathrm{i}$ «Ternopil Bioscience», де магістранти можуть висвітлювати результати своїх наукових досліджень.

Організаційно-методичне забезпечення навчального процесу базуеться на розробці навчально-методичного комплексу дисципліни, який включає: робочу програму навчальної дисципліни; силабус; підручники і навчальні посібники; методичні матеріали і завдання до лекційних і практичних занять; індивідуальні завдання для самостійної роботи студентів; поточні та підсумкові контрольні роботи для перевірки рівня засвоєння студентами навчального матеріалу.

Найбільш ефективною формою подачі матеріалу є лекція у формі бесіди, що дає змогу студентам співставити теоретичні знання й практичні навички з інформацією про професійне навчання вчителів природничих наук в США. Також не можна не відзначити факт плідного поєднання бесіди з елементами дискусї, котра стає можлива через постановку проблемних питань. Установлення зв'язку нового матеріалу 3 наступним і підготовка студентів до сприйняття окремих тем курсу відбувається на основі принципу перспективності. При організації занять передбачається зв'язок вивченого матеріалу 3 наступним. Таким чином створюеться база для міцного системного засвоєння наступних тем курсу. Закріплення одержаних знань та формування необхідних практичних умінь і навичок відбувається на основі принципу зв'язку теорії 3 практикою. Останній передбачає зв'язок викладання 3 життям, формування вмінь застосовувати набуті знання й навички в практичній, професійній та суспільній діяльності [1, с. 123].

Впродовж вивчення такого курсу активно застосовується «перевернута лекція»педагогічна модель, в якій типова подача лекційного матеріалу здійснюеться здобувачами освіти, а не викладачем. Перед початком декції студенти отримують план з основними питаннями, що будуть розгдядатися під час лекції, викдадач повідомляе і дає коротку характеристику основної рекомендованої дітератури. Кожен студент обирає собі тему і готує матеріал з презентацією. Інші студенти, слухаючи таку лекцію, готують питання та дискутують з доповідачем. Під час такої лекції студент не отримуе готових висновків, а, беручи активну участь у ній, сприймаючи іiі полемічну суть, стає спільником пошуку i, як результат, стає спроможним перейти до самостійних висновків. Наступним кроком є написання короткого есею за темою та представлення його ангдійською мовою.

Вимоги сьогодення щодо університетської освіти формують такі сучасні особливості викладання курсу «Підготовка вчителів природничих наук в університетах США», як студентоцентризм, увага до формування тих компетентностей майбутніх учителів природничих наук, які забезпечують якісний полікультурний освітній процес у закладах загальної середньої освіти за предметною спеціальністю «Природничі науки». Зміст дисципліни демонструе, що оволодіння знаннями дозводяе студентам краще орієнтуватися в реаліях сьогодення і забезпечує на основі засвоєних знань їхню конкурентоспроможність на національному, європейському та світовому ринках праці. При виборі тематичного та інформаційного наповнення важливо зважати на реалії сучасного розвитку суспільства. Запровадження аналогічних курсів у вітчизняну вищу освіту дасть змогу вдосконалити систему підготовки вчителів природничих наук України, підвищивши якість як педагогічної діяльності освітян, так і здобувачів освіти. 
Висновки. Впровадження в освітній процес підготовки майбутніх учителів природничих наук вибіркової навчальної дисципліни «Підготовка вчителів природничих наук в університетах США» $\mathrm{e}$ ефективним засобом забезпечення «паритетної моделі» білінгвальної освіти майбутніх учителів природничої галузі та «моделі, що витісняє». Вивчення навчальної дисципліни передбачає двоєдину мету формування у студентів системи знань про концепцію підготовки вчителів природничого профілю в США (структуру, особливості змісту, форм й методів навчання вчителів природничих наук в умовах неперервної педагогічної освіти) та адаптацію цих знань до освітнього процесу в Україні; формування навичок міжкультурної взаємодії. Ефективною технологією навчання цієї дисципліни є використання методики із застосуванням різної дози допомоги (за Ю. Бабанським) при виконанні пізнавальних завдань. Їі впровадження забезпечує кожному студентові умови для максимального задоволення пізнавальних потреб, формування комунікативних умінь, передбачає поступовий перехід від колективних форм роботи до частково самостійних і повністю самостійних, виконання завдань, складність яких зростає.

Перспективним для подальшого наукового пошуку вважаємо розробку контенту інших навчальних дисциплін професійної підготовки вчителів.

\section{Список використаних джерел:}

1. Боднарчук Т. В. Моделі білінгвальної освіти та їх функціонування в сучасній українській школі. Педагогічна освіта: теорія $і$ практика: зб. наук. працьь / Кам'янець-Подільський національний університет імені Івана Огієнка; гол. ред. Каньоса П. С. Кам'янецьПодільський: КПНУ, 2013. Вип. 14. С. 37-42.

2. Горошкіна О. Лінгводидактичні засади викладання курсу «Методика викладання дінгводидактичних дисципдін» у магістратурі. Вісник АНУ імені Тараса Шевченка. Педагогічні науки. № 24 (259). Ч. II. 2012. С. 119-127.

3. Ігнатенко К. О. Білінгвальна освіта як засіб міжкультурної підготовки вчителя іноземної мови. Вісник психології $і$ педагогіки: зб. матер. студ. наук. конф.«Сучасна іншомовна освіта очима студентів», Київ, 26 лютого 2014 р. Вип. 14. К., 2014. С. 108-114.

4. Микитенко Н. О. Теорія і технології формування іншомовної професійної компетентності майбутніх фахівців природничих спеціальностей: дис. ... д-ра пед. наук: 13.00.04, 13.00.02. Тернопіль, 2011. 534 с.

5. Олендр Т. М. Робоча програма навчальної дисципліни «Підготовка вчителів природничих наук в університетах США» для здобувачів другого (магістерського) рівня вищої освіти, які навчаються за освітньо-професійною програмою «Середня освіта (Природничі науки)» за спеціальністю 014.15 Середня освіта (Природничі науки). 2020.17 с. $\quad$ URL.: https://elr.tnpu.edu.ua/login/index.php

6. Олендр Т. М., Дробик Н. М., Степанюк А. В. Впровадження елементів білінгвального навчання у професійну підготовку майбутніх учителів природничих наук. Підготовка майбутніх учителів фізики, хімії, біологї та природничих наук у контексті вимог Нової українськой щколи: матеріали III міжн. наук.-практ. конф. м. Тернопіль, 20 травня $2021 \mathrm{p}$. Тернопіль, 2021. С. 24-28.

7. Ситняківська С. М., Хдивнюк М.Г. Особливості впровадження білінгвального навчання у технічних навчальних закладах України. Вісник Житомирського державного університету імені Івана Франка. 2015. Вип. 6. С. 167-172.

8. Ситняківська С. М. Історико-педагогічна ретроспектива проблеми становлення білінгвальної освіти у вищих навчальних закладах України. Вісник Житомирського державного університету імені Івана Франка. Житомир, 2012. № 61. С. 121-128.

9. Цюра С. Б., Боднарчук Т. В. Розвиток білінгвальної освіти в Австрії: історія, сучасний стан і перспективи розвитку в Україні: монографія. Кам'янець-Подільський, 2019. 296 с.

10. Ширин А.Г. Педагогические аспекты билингвизма : развитие новой научной школы. Ментор. 2003. № 2. С. 34-38.

11. Щур Н., Олендр Т., Степанюк А. Підготовка вчителя природничих наук в університетах США: монографія. ТНПУ ім. В. Гнатюка. 2020. 266 с.

ज3 178 
12. Stepanyuk, A., Olendr T. Training of Future Teachers of Natural Sciences in Pedagogical Universities of Ukraine: Realities and Prospects. Pedagogika-Pedagogy. Vol. 91, 2019, No. 9. Pp. 1319-1326.

\section{Reference:}

1. Bodnarchuk, T. V. (2013). Modeli bilinhvalnoi osvity ta yikh funktsionuvannia $v$ suchasniy ukrainskiy shkoli [Models of bilingual education and their functioning in modern Ukrainian school]. Pedahohichna osvita: teoriia i praktyka, 14, 37-42 [in Ukrainian].

2. Horoshkina, O. (2012). Linhvodydaktychni zasady vykladannia kursu «Metodyka vykladannia linhvodydaktychnykh dystsyplin» $\mathrm{u}$ mahistraturi [Linguodidactic basics of teaching the course "Methods of studying linguistic disciplines" during the master course]. Visnyk LNU imeni Tarasa Shevchenka. Pedahohichni nauky, 24 (259), II, 119-127 [in Ukrainian].

3. Ihnatenko, K. O. (2014). Bilinhvalna osvita yak zasib mizhkulturnoi pidhotovky vchytelia inozemnoi movy [Bilingual education as a means of foreign language teacher intercultural training], Suchasna inshomovna osvita ochyma studentiv: zb. mater. stud. nauk. konf. [Modern foreign language education through the eyes of students, Collection of scientific works]. Kyiv [in Ukrainian].

4. Mykytenko, N. O. (2011). Teoriia $i$ tekhnolohii formuvannia inshomovnoi profesiynoi kompetentnosti maybutnikh fakhivtsiv pryrodnychykh spetsialnostei [Theory and technologies of forming professional foreign language competence of prospective specialists of sciences]. (Doctor's thesis). Ternopil [in Ukrainian].

5. Olendr, T. M. (2020). Robocha prohrama navchalnoi dystsypliny «Pidhotovka vchyteliv pryrodnychykh nauk v universytetakh SShA» dlia zdobuvachiv druhoho (mahisterskoho) rivnia vyshchoi osvity, yaki navchaiutsia za osvitno-profesiinoiu prohramoiu «Serednia osvita (Pryrodnychi nauky)» za spetsialnistiu 014.15 Serednia osvita (Pryrodnychi nauky) [Academic course working program of the discipline "Training of science teachers in US universities" for students at the second (master's) level of higher education, studying in the educational-professional program "Secondary education (Natural Sciences)" in specialty 014.15 Secondary education (Natural sciences)]. Retrieved from https://elr.tnpu.edu.ua/login/index.php [in Ukrainian].

6. Olendr, T. M., Drobyk, N. M., \& Stepanyuk, A. V. (2021). Vprovadzhennia elementiv bilinhvalnoho navchannia u profesiynu pidhotovku maibutnikh uchyteliv pryrodnychykh nauk [Introduction of the elements of bilingual education in professional training of future natural sciences teachers], Pidhotovka maibutnikh uchyteliv fizyky, khimii, biolohii ta pryrodnychykh nauk u konteksti vymoh Novoi ukrainskoi shkoly: materialy III mizhn. nauk.-prakt. konf. m. [Training of future teachers of Physics, Chemistry, Biology and natural sciences in the context of the requirements of the New Ukrainian School, Proceedings of the 3rd International Scientific and Practical Conference]. Ternopil [in Ukrainian].

7. Sytniakivska, S. M., \& Khlyvniuk, M. H. (2015). Osoblyvosti vprovadzhennia bilinhvalnoho navchannia $\mathrm{u}$ tekhnichnykh navchalnykh zakladakh Ukrainy [Features of implementation of the bilingual education in the technical educational institutions of Ukraine]. Visnyk Zhytomyrskoho derzhavnoho universytetu imeni Ivana Franka, 6, 167-172 [in Ukrainian].

8. Sytniakivska, S. M. (2012). Istoryko-pedahohichna retrospektyva problemy stanovlennia bilinhvalnoi osvity $\mathrm{u}$ vyshchykh navchalnykh zakladakh Ukrainy [Historical-pedagogical retrospective of the bilingual education problem in the Ukrainian higher educational institutions]. Visnyk Zhytomyrskoho derzhavnoho universytetu imeni Ivana Franka, 61, 121-128 [in Ukrainian].

9. Tsiura, S. B., \& Bodnarchuk, T. V. (2019). Rozvytok bilinhvalnoi osvity $v$ Avstrii: istoriia, suchasnyi stan i perspektyvy rozvytku $v$ Ukraini [Development of bilingual education in Austria: history, current state and prospects of development in Ukraine]. Kamianets-Podilskyi [in Ukrainian].

10. Shirin, A. G. (2003). Pedagogicheskiye aspekty bilingvizma: razvitiye novoy nauchnoy shkoly [Pedagogical aspects of bilingualism: the development of a new scientific school]. Mentor, 2, 34-38 [in Russian].

11. Shchur, N., Olendr, T., \& Stepaniuk, A. (2020). Pidhotovka vchytelia pryrodnychykh nauk $v$ universytetakh SShA [Science teachers training in US universities]. TNPU im. V. Hnatiuka [in Ukrainian].

12. Stepanyuk, A., \& Olendr, T. (2019). Training of Future Teachers of Natural Sciences in Pedagogical Universities of Ukraine: Realities and Prospects. Pedagogika-Pedagogy, 91 (9), 1319-1326 [in English]. 
Olendr T. M., orcid.org/0000-0002-1665-6413

Stepanyuk A. V.,

\section{BILINGUAL EDUCATION OF NATURAL SCIENCES TEACHERS} orcid.org/0000-0003-3258-9182

\section{AS AN IMPERATIVE OF OUR TIME}

The article deals with the problem of introduction of the elements of bilingual education in natural sciences teachers professional training. It has been found out that Ukraine has historical experience of introducing bilingual education in general secondary education institutions. It has been revealed that the main problem, in this perspective, is the training of the teachers who would be able to provide bilingual education for school students. The content of the elective course «Science teachers training in US universities» which is taught in English, as one of the means of ensuring a parity model of bilingual education for future natural sciences teachers and a model that displaces has been revealed. Learning of a course involves a dual purpose - the formation of students' knowledge of the concept of natural sciences teachers training in the United States (structure, features of the content, forms and methods of science teachers training under conditions of continuous pedagogical education) and adaptation of this knowledge to the educational process in Ukraine; formation of intercultural interaction skills. The peculiarity of this course is that teaching is carried out in English depending on the level of students' foreign language competence formation.

It has been established that the teaching methods which include the use of different dosages of help (according to Yu. Babanskyi) during the performance of cognitive tasks are effective. The use of such teaching methods allows to provide each student with the conditions for the maximum satisfaction of his cognitive needs and formation of communicative skills. These methods involve a gradual transition from collective forms of work to partially independent and fully independent and performing of the tasks, the complexity of which is growing.

Key words: bilingual education, future teachers, elective course, content, dosage of help.

Дата надходження статmі: 07.052021 p. Рецензент: доктор педагогічних наук, професор Задорожна I. П.

\section{ОСОБЯИВОСТІ ОРГАНІЗАЦІЇ ДИСТАНЦІЙНОГО НАВЧАННЯ ВЧИТЕЛІВ В УМОВАХ КАРАНТИННИХ ОБМЕЖЕНЬ}

Стаття присвячена розгляду особливостей використання технологій дистанційного навчання у процесі підвищення кваліфікації педагогів на прикладі досвіду Комунального закладу Сумський обласний інститут післядипломної педагогічної освіти. Представлено аналіз теоретичних досліджень та досвіду Комунального закладу Сумський обласний інститут післядипломної педагогічної освіти щодо практичної реалізацї онлайн-навчання з використанням дистанційних технологій в умовах карантинних обмежень, викликаних пандемією COVID19, що вимагає системної трансформації організаційних і педагогічних основ системи післядипломної педагогічної освіти. Проаналізовано особливості дистанційного

*(C) Петрова Л. Г.

*(C) Подліняєва О. О.

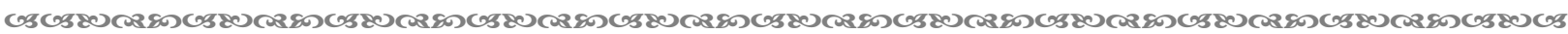
180 